$1-1-2003$

\title{
Wildlife knowledge among migrants in southern Sumatra, Indonesia: implications for conservation
}

Philip J. Nyhus

Colby College, pjnyhus@colby.edu

Sumianto Tilson

Ronald Tilson

Follow this and additional works at: https://digitalcommons.colby.edu/faculty_scholarship

Part of the International and Area Studies Commons, Nature and Society Relations Commons, and the Public Affairs, Public Policy and Public Administration Commons

\section{Recommended Citation}

Nyhus, Philip J.; Tilson, Sumianto; and Tilson, Ronald, "Wildlife knowledge among migrants in southern Sumatra, Indonesia: implications for conservation" (2003). Faculty Scholarship. 55.

https://digitalcommons.colby.edu/faculty_scholarship/55

This Article is brought to you for free and open access by Digital Commons @ Colby. It has been accepted for inclusion in Faculty Scholarship by an authorized administrator of Digital Commons @ Colby. 


\title{
Wildlife knowledge among migrants in southern Sumatra, Indonesia: implications for conservation
}

\author{
PHILIP J. NYHUS ${ }^{1 *}$, SUMIANTO $^{2}$ AND RONALD TILSON ${ }^{2}$ \\ ${ }^{1}$ Environmental Studies Program, Franklin and Marshall College, Lancaster, PA 17604-3003, USA and ${ }^{2}$ Sumatran Tiger Project, c/o Minnesota \\ Zoological Garden, 13000 Zoo Boulevard, Apple Valley, MN 55124, USA \\ Date submitted: 23 October 2002 Date accepted: 25 February 2003
}

\section{SUMMARY}

The value of traditional ecological knowledge for biodiversity research and conservation is widely recognized. The value of wildlife knowledge provided by recent migrants is less clear. Photographs of 10 mammal species were shown to 622 individuals in communities near Way Kambas National Park in Sumatra, Indonesia, to assess wildlife knowledge among recent migrants and to identify socio-economic variables that can be used to identify more knowledgeable informants. Knowledge scores were categorized by taxonomic family, genus and species. Large, charismatic and abundant animals were identified more frequently than smaller and more secretive animals. Higher knowledge scores were significantly associated with males, higher educational attainment and past experience with these animals. Number of years respondents had lived in the area and respondent age were also good predictors of higher scores. The characteristics of animals that were likely to be identified more accurately were assessed. Generic terms used to describe animals can confound individual responses. Biodiversity research, conservation and education programmes frequently rely on 'local' knowledge to inform management and policy. This information can be a valuable addition to field-based efforts to identify the distribution and abundance of rare endangered species. With more and more migrants living near the world's wildlife protected areas, care must be taken to understand how human demographic shifts may affect such studies.

Keymords: Way Kambas National Park, Sumatra, tiger, elephant, indigenous knowledge, conservation

\section{INTRODUCTION}

The study and use of traditional ecological knowledge is widely considered an important component of biodiversity assessments and conservation in much of the tropics (Posey 1993; Berkes 1999). Wildlife knowledge assessments can benefit research because aboriginal peoples with a long

\footnotetext{
* Correspondence: Dr Philip Nyhus Tel: +1 7173584555 Fax: +1

7172914186 e-mail: philip.nyhus@fandm.edu
}

history of interaction with the area's natural resources may have considerable knowledge of the local flora and fauna (Huntington 2000). These assessments are important for conservation because knowledge about wildlife and conservation can be significant influences on people's attitudes toward wildlife and ultimately their support for conservation (Kellert 1996). As a result, this information can help to determine the need for, or characteristics of, biodiversity conservation and awareness programmes.

Areas of the world containing high biological diversity frequently are inhabited by indigenous people, and the proportion of indigenous peoples living in and near protected areas can exceed $80 \%$ (WWF [Worldwide Fund for Nature] 2000). In regions where residents have long histories of exploiting local wildlife resources, knowledge of animals and their habitats is usually well defined, the language is rich with descriptive terms for even subtle differences (Gadgil et al. 1993), and the value of this information for research and conservation is high.

In many other areas, however, indigenous people have been forced to move or are outnumbered by large numbers of new migrants. The research and conservation value of wildlife knowledge obtained from recent migrants who may have less experience with local natural resources is less clear. Thus, the value of 'local' wildlife knowledge may vary considerably from location to location (Berkes et al. 2000). This is particularly true in the Republic of Indonesia, where decades of state-sponsored migration has resulted in the translocation of hundreds of thousands of migrants from the densely-populated islands of Java, Bali and Madura to the country's 'outer islands' of Sumatra, Indonesian Borneo (Kalimantan), Indonesian New Guinea (Irian Jaya), Celebes (Sulawesi), and other smaller islands (Fearnside 1997). Many more migrants have followed these state-sponsored transmigrants, increasingly blurring the definition of 'local' populations.

Wildlife knowledge has relevance where the conservation of endangered animals hinges on the support of local communities. The critically endangered Sumatran tiger (Panthera tigris sumatrae) and endangered Sumatran elephant (Elephas maximus sumatranus), found only on the island of Sumatra, Indonesia, are excellent examples. In this century in Sumatra, tiger and elephant populations have plummeted and today only approximately 500 tigers and 2800 to 4800 elephants are thought to remain in the forests of Sumatra (Blouch \& Haryanto 1984; Blouch \& Simbolon 1985; 
Santiapillai \& Jackson 1990; Tilson et al. 1994a, b). Both are threatened in the wild unless their conservation is supported by people living near their dwindling habitat (Tilson et al. 1994a, b; Nyhus et al. 1999, 2000). Recent studies by the World Bank suggest that the last lowland forests outside of the island's protected areas are likely to disappear by 2005 (World Bank 2001).

In some areas, such as in communities near Way Kambas National Park in Lampung Province, more than $80 \%$ of people living near tiger and elephant protected areas are migrants or their descendents from Java, Madura and Bali (Scholz 1983; Fearnside 1997). Similar patterns are developing in other provinces. Consequently, the situation today in communities bordering Way Kambas National Park may represent a window into the future of many of Sumatra's, and South-east Asia's, protected areas (Nyhus et al. 1999; Tilson et al. 2001). The magnitude of the problem is evident when juxtaposed with Indonesia's recent history with tigers; the country's two other tiger sub-species, the Bali $(P . t$. balica $)$ and Javan $(P . t$. sondaica), were declared extinct within the last 50 and 20 years, respectively (Seidensticker 1987; Nowell \& Jackson 1996).

In this study, we explore the level of wildlife knowledge among migrants living near Way Kambas National Park in southern Sumatra, Indonesia. We use photographs of ten different mammals to assess wildlife knowledge and to explore whether a subset of socio-economic variables can be used to help identify more knowledgeable informants.

\section{METHODS}

\section{Study site}

Way Kambas National Park is located in Lampung Province in south-eastern Sumatra (Fig. 1). The $1300 \mathrm{~km}^{2}$ Park has been identified as an important location for conservation because it is one of Sumatra's last lowland rainforests, contains significant populations of tigers, elephants and other endangered species, and is one of only six national parks in

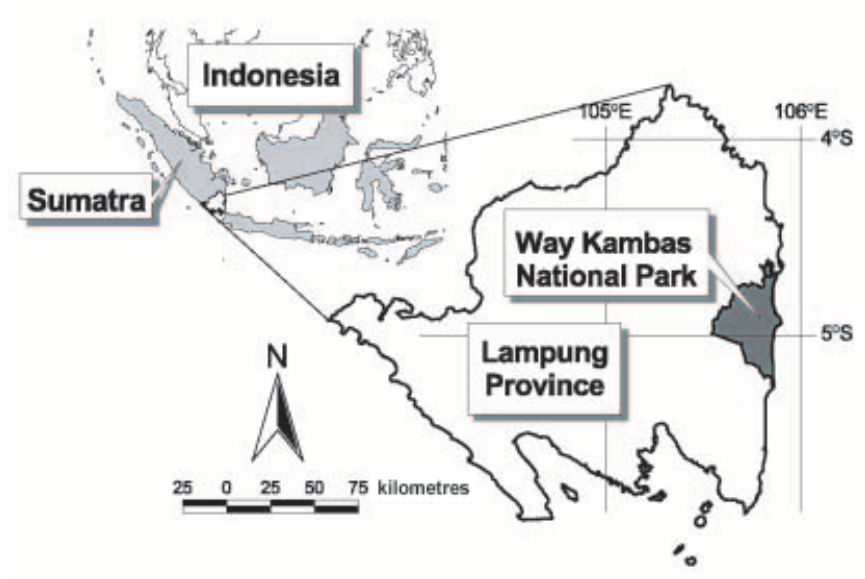

Figure 1 Map of Way Kambas National Park in Lampung, Sumatra, Indonesia.
Sumatra (Tilson et al. 1994a, b; Ministry of Forestry 1995). The Park is home to Indonesia's first Elephant Training Center, a centre established in 1985 to domesticate and train wild elephants translocated from other areas of Sumatra. The Center today has more than 150 elephants and is one of southern Sumatra's most popular tourist destinations (Nyhus et al. 2000). At least 35 tigers and 300 elephants are thought to reside within the Park boundary (Santiapillai \& Suprahman 1985; Tilson et al. 1994a, b; Franklin et al. 1999). The area surrounding the Park is dominated by migrants who rely on agriculture as a principal livelihood strategy (BPS [Biro Pusat Statistik] 1995). Population densities are high, ranging from $60-700$ people $\mathrm{km}^{-2}$ (including agricultural land) in the 27 villages immediately bordering the park (Tilson et al. 2001).

\section{Data collection and analysis}

A household survey was carried out using a questionnaire administered by two of the authors (PJN and S) and five students from the University of Lampung between July and November 1996. The survey was administered to a stratified systematic sample of 622 households in 10 of 27 villages bordering the Park. Two villages with extensive borders with the Park were selected in each of four sub-districts and one village was selected in each of the remaining two sub-districts (one of which had only one village bordering the Park). The questionnaire was designed to gather baseline data from a representative sample of people living in communities near the Park on basic respondent and household socio-economic and demographic characteristics and their experiences with human-wildlife conflict, attitudes, and wildlife knowledge. This paper addresses only the wildlife knowledge portion of this survey.

Between $2.9 \%$ and $15.2 \%$ (average $=8.0 \%$ ) of households in each of the ten villages were sampled. The total population in the ten villages surveyed was approximately 35625 individuals, so approximately $1.7 \%$ of all villagers were surveyed. Interviews were carried out with one individual in each household. Enumerators visited every fifth household, staggering their starting locations. When present, the head of the household, or someone chosen by the head of the household, was interviewed. Otherwise, the adult (or in several cases, children 14-17 years old) who greeted the enumerator was interviewed. If multiple people were present, spectators were asked to refrain from answering questions. If spectators provided unsolicited help, potentially biased answers were noted and excluded from the analysis. Households where no one was present were revisited at least once later the same day. If no one was home, the adjacent house was visited. Questions were written and asked in Indonesian, the national language. Questions were translated into Javanese or explained using alternative wording when respondents could not understand the original questions.

Wildlife knowledge was evaluated in the household survey based on the ability of respondents to use photographs to 
Table 1 English names, Indonesian names, and taxa of species used in the wildlife knowledge questions. Sources used for classification: Lekagul and McNeely (1977), Nowak (1991) and Corbet and Hill (1992).

\begin{tabular}{|c|c|c|c|c|c|}
\hline English & Indonesian & Order & Family & Genus & Species \\
\hline Asian elephant & Gajah & Proboscidea & Elephantidae & Elephas & maximus \\
\hline Barking deer & Kijang & Artiodactyla & Cervidae & Muntiacus & muntjak \\
\hline Golden cat & Kucing emas & Carnivora & Felidae & Felis & temmincki \\
\hline Leopard cat & Kucing batu & Carnivora & Felidae & Felis & bengalensis \\
\hline Malay civet & Tenggalong & Carnivora & Viverridae & Viverra & tangalunga \\
\hline Malayan tapir & Tapir, ternuk & Perissodactyla & Tapiridae & Tapirus & indicus \\
\hline Masked palm civet & Musang merah & Carnivora & Viverridae & Paguma & larvata \\
\hline Sumatan tiger & Harimau sumatera & Carnivora & Felidae & Panthera & tigris \\
\hline Sumatran rhino & Badak sumatera & Perissodactyla & Rhinocerotidae & Dicerorhinus & sumatrensis \\
\hline Sun Bear & Beruang & Carnivora & Ursidae & Helarctos & malayanus \\
\hline
\end{tabular}

identify 10 mammal species found within the Park (Table 1). These photographs represent four taxonomic orders, seven families, and nine genera. The photographs were obtained in late 1995 and early 1996 using infra-red remote camera units from Trailmaster Corporation set up within the core area of the forest by staff of the Sumatran Tiger Project (STP 1996; Franklin et al. 1999). Each respondent was shown the same pictures on laminated sheets in the same order. For each picture, respondents were asked if they knew the name of the animal, whether they had ever seen this animal, and whether they thought the animal was found in Way Kambas. When asked to identify the animal, respondents were asked if there was an alternate name for the species. Both answers were noted but the more specific term was used in the analysis if more than one response was provided.

Results were entered into a database and analysed using SPSS (1999). To generate wildlife knowledge scores, responses were coded and categorized by taxonomic order, family and genus based on the common name of the animal provided by respondents. Knowledge scores were calculated by giving one point for each correct answer at each taxonomic level. The three scores were summed to generate an aggregate wildlife knowledge score. Aggregate scores were divided into low, medium, and high categories based on standard deviation increments from the mean. An answer was scored correct to the genus level if it clearly identified the animal and could not be used to classify another animal in the same taxon. For example, the response macan, a frequent response to the tiger picture and a term used for carnivorous species in more than one taxonomic family, was classified correct only to the taxonomic order Carnivora because other felids are also called macan. A more descriptive answer, such as macan gembong, a term only used for tigers, was considered correct to the genus level. The term badak (rhino) for the rhino picture would be considered correct to the genus level because no other animal is referred to by that name in Sumatra. The first responses provided by the respondents were noted. Respondents were given the option to further clarify ambiguous answers (for example, a specific type of macan). Indonesian names for the animals were referenced by Departemen Pendidikan dan Kebudayaan (1989) and in consultation with Indonesian staff of the Sumatran Tiger Project.

\section{RESULTS}

The age of respondents ranged from 14 to 92 years old, with a mean age of 38.5 years. Sixty-five per cent were men and $35 \%$ women. Most originated from Java or had one or more parents that originated from Java $(92.2 \%)$; others were from the islands of Bali, Madura, Sumatra and other Outer Islands. A majority (78\%) had no more than a primary school education and only one had completed university education.

Respondents used a total of 113 different names to describe the ten different species shown to them in photographs. At the level of taxonomic order, almost all respondents correctly identified the elephant and tiger (Fig. 2). More than half also correctly identified the barking deer and leopard cat. At the taxonomic family level, only the elephant and barking deer were correctly identified by more than $50 \%$ of respondents. At the taxonomic genus level, the majority of respondents identified only the elephant correctly. Scores for the elephant, rhino, sun bear and tapir were similar across taxa because only one species exists on Sumatra so the answer 'elephant,' 'rhino,' 'sun bear' and 'tapir' were considered correct to the genus level. At the genus level, fewer than 5\% correctly identified the two civits or small felids (Fig. 2).

When asked whether they believed these animals existed in the Park, a majority of respondents answered yes for all the animals (Fig. 3). The elephant had the highest proportion of 'yes' answers (99\%), and the Sumatran rhino the least (66\%). When asked whether they had personally observed these animals, only the elephant and the barking deer were reportedly observed by more than $50 \%$ of the respondents. The rhino was also the least likely animal to have been observed, with only $23 \%$ of respondents claiming to have observed this animal (Fig. 3).

For the six species where distinctions were made at all three taxonomic categories, knowledge scores declined from order to family to genus for every animal. For four of these species (masked palm civet, Malay civet, golden cat and leopard cat), less than $0.5 \%$ of respondents correctly ident- 


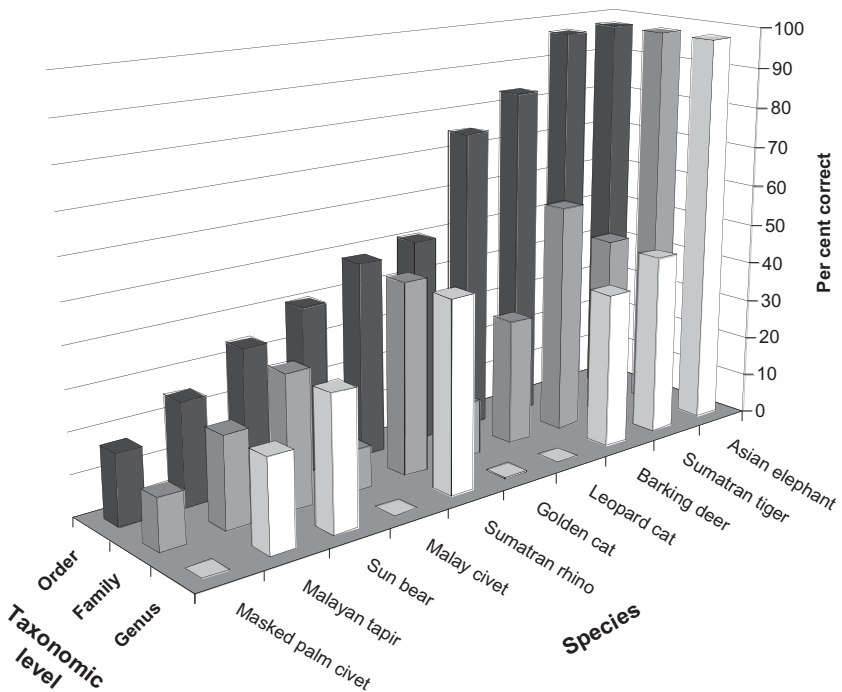

Figure 2 Percentage of respondents correctly classifying wildlife by taxa $(n=622)$. See Table 1 for complete names of these species.

ified them to the genus level, meaning that the answers were sufficiently vague (for example, civet) that they could not be used to rule out another similar animal (such as another type of civet).

Higher wildlife knowledge scores were significantly associated with respondents who were men, young or middle-aged adults, and had completed at least some formal education (Table 2). The number of respondents who had completed more than a primary school education was low $(20.6 \%)$ and the highest mean knowledge scores were among

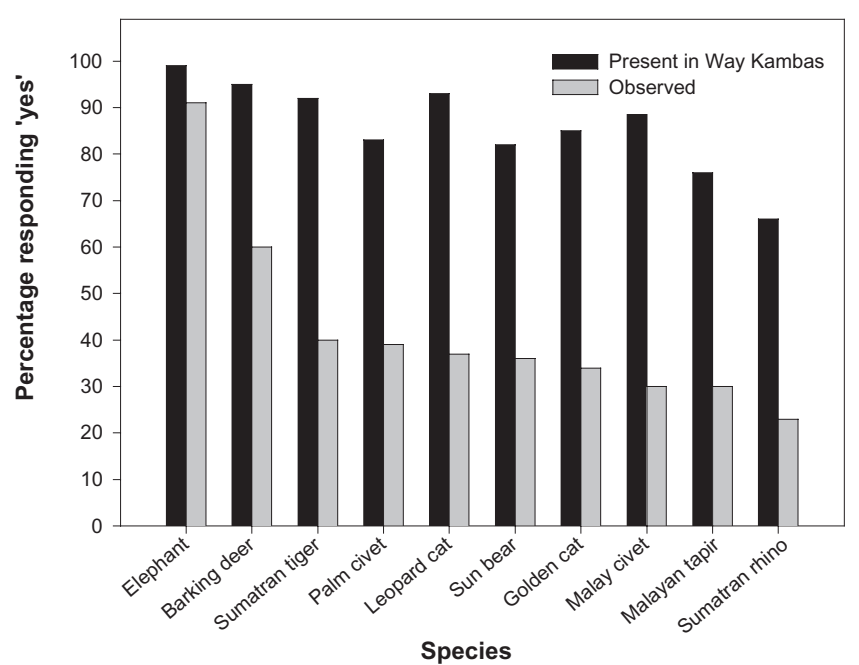

Figure 3 Proportion of respondents who believed the following animals presented in photographs were present in Way Kambas National Park, and the proportion that claimed to have observed these animals in person $(n=317-577)$.

those that had attained at least a middle school education. Scores tended to increase with increasing number of years respondents had lived in Lampung, except for respondents with 39 or more years of residency (Table 2). Knowledge scores were generally higher, but not significant, for respondents who were born in Sumatra or had one or more parents born in Sumatra. Higher knowledge scores were also significantly associated with respondents who claimed to have personally observed these animals for all the animals except the Sumatran rhinoceros and the Sumatran tiger (Table 3).
Table 2 Relationship between demographic characteristics of respondents in the household survey and aggregate wildlife knowledge scores calculated as the sum of mean order, family, and genus scores for 10 different species $($ maximum score $=30)$. Age groups and years in Lampung based on increments of 1 standard deviation $(-2,-1$, $+1,+2++)$. Respondent origin based on where respondent, mother and father were born. ns $=$ not significant, $* * * 0.001$, $* p<0.05$.

\begin{tabular}{|c|c|c|c|c|c|c|}
\hline Factor & Category & $\begin{array}{l}\text { No. } \\
\text { respondents }\end{array}$ & $\begin{array}{l}\text { Mean } \\
\text { knomledge } \\
\text { score }\end{array}$ & $S D$ & $F$ & $p$ \\
\hline Gender & $\begin{array}{l}\text { Male } \\
\text { Female }\end{array}$ & $\begin{array}{l}396 \\
216\end{array}$ & $\begin{array}{l}13.58 \\
10.61\end{array}$ & $\begin{array}{l}5.80 \\
4.91\end{array}$ & 40.77 & 0.000 ** \\
\hline Age & $\begin{array}{l}0-14 \\
15-29 \\
30-44 \\
45-59 \\
60+\end{array}$ & $\begin{array}{r}4 \\
185 \\
221 \\
127 \\
57\end{array}$ & $\begin{array}{l}12.00 \\
12.61 \\
12.57 \\
13.75 \\
10.72\end{array}$ & $\begin{array}{l}7.26 \\
5.15 \\
6.01 \\
5.59 \\
5.28\end{array}$ & 2.94 & $0.020^{*}$ \\
\hline Education & $\begin{array}{l}\text { None } \\
\text { Primary } \\
\text { Middle }+\end{array}$ & $\begin{array}{r}96 \\
393 \\
128\end{array}$ & $\begin{array}{r}9.76 \\
12.14 \\
15.62\end{array}$ & $\begin{array}{l}5.19 \\
5.41 \\
5.45\end{array}$ & 34.77 & 0.000 ** \\
\hline Years in Lampung & $\begin{array}{l}0-16 \\
17-27 \\
28-38 \\
39+\end{array}$ & $\begin{array}{r}70 \\
238 \\
211 \\
72\end{array}$ & $\begin{array}{l}11.31 \\
12.25 \\
13.80 \\
11.81\end{array}$ & $\begin{array}{l}5.62 \\
5.22 \\
5.98 \\
5.81\end{array}$ & 5.22 & $0.001^{* *}$ \\
\hline Respondent origin & $\begin{array}{l}\text { Sumatra } \\
\text { Sumatra and Java/Bali } \\
\text { Java/Bali } \\
\text { Other }\end{array}$ & $\begin{array}{r}19 \\
190 \\
355 \\
21\end{array}$ & $\begin{array}{l}13.74 \\
13.43 \\
12.30 \\
11.19\end{array}$ & $\begin{array}{l}5.82 \\
5.75 \\
5.49 \\
5.76\end{array}$ & 2.41 & $0.066 \mathrm{~ns}$ \\
\hline
\end{tabular}


Table 3 Comparison of wildlife knowledge scores by experiences of respondents observing animals in the wild. Respondents were shown pictures of these animals and asked, 'Have you ever observed this animal?' $n=$ number of respondents, $\mathrm{ns}=$ not significant, $* * p<0.001$.

\begin{tabular}{|c|c|c|c|c|c|c|}
\hline Species & $n$ & Mean & $S D$ & $t$ & $d f$ & $p(2-$ tailed $)$ \\
\hline \multicolumn{7}{|c|}{ Elephant } \\
\hline Yes & 514 & 13.10 & 5.57 & \multirow[t]{2}{*}{4.21} & \multirow[t]{2}{*}{563} & \multirow[t]{2}{*}{$0.000 * *$} \\
\hline No & 51 & 9.67 & 5.42 & & & \\
\hline \multicolumn{7}{|c|}{ Barking deer } \\
\hline Yes & 290 & 14.69 & 5.19 & \multirow[t]{2}{*}{6.74} & \multirow[t]{2}{*}{479} & \multirow[t]{2}{*}{$0.00^{* * *}$} \\
\hline No & 191 & 11.44 & 5.15 & & & \\
\hline \multicolumn{7}{|c|}{ Leopard cat } \\
\hline Yes & 164 & 14.55 & 5.13 & \multirow[t]{2}{*}{3.89} & \multirow[t]{2}{*}{438} & \multirow[t]{2}{*}{$0.000 * *$} \\
\hline No & 276 & 12.50 & 5.48 & & & \\
\hline \multicolumn{7}{|c|}{ Malay civet } \\
\hline Yes & 123 & 16.64 & 5.36 & \multirow[t]{2}{*}{8.30} & \multirow[t]{2}{*}{406} & \multirow[t]{2}{*}{$0.000 * *$} \\
\hline No & 285 & 12.03 & 5.06 & & & \\
\hline \multicolumn{7}{|c|}{ Malayan tapir } \\
\hline Yes & 122 & 15.13 & 5.25 & \multirow[t]{2}{*}{4.30} & \multirow[t]{2}{*}{406} & \multirow[t]{2}{*}{$0.000^{* * *}$} \\
\hline No & 286 & 12.62 & 5.47 & & & \\
\hline \multicolumn{7}{|c|}{ Sumatran rhinoceros } \\
\hline Yes & 95 & 13.87 & 4.83 & \multirow[t]{2}{*}{1.16} & \multirow[t]{2}{*}{414} & \multirow[t]{2}{*}{$0.246 \mathrm{~ns}$} \\
\hline No & 321 & 13.14 & 5.54 & & & \\
\hline \multicolumn{7}{|c|}{ Golden cat } \\
\hline Yes & 140 & 14.88 & 4.95 & \multirow[t]{2}{*}{4.25} & \multirow[t]{2}{*}{413} & \multirow[t]{2}{*}{$0.000^{* * *}$} \\
\hline No & 275 & 12.52 & 5.54 & & & \\
\hline \multicolumn{7}{|c|}{ Masked palm civet } \\
\hline Yes & 161 & 16.31 & 5.30 & \multirow[t]{2}{*}{9.32} & 414 & $0.000 * *$ \\
\hline No & 255 & 11.57 & 4.89 & & & \\
\hline Sun bea & & & & & & \\
\hline Yes & 154 & 16.05 & 4.85 & 7.23 & 431 & $0.000 * *$ \\
\hline No & 279 & 12.32 & 5.29 & & & \\
\hline Sumatra & & & & & & \\
\hline Yes & 190 & 12.66 & 5.71 & -0.04 & 470 & $0.965 \mathrm{~ns}$ \\
\hline No & 282 & 12.68 & 5.59 & & & \\
\hline
\end{tabular}

\section{DISCUSSION}

Time, funding and human resource limitations often constrain the ability of researchers to survey a large and representative sample of a human community's population. To reduce these limitations and to increase the efficiency, effectiveness and validity of a survey, it is helpful to select informants who are knowledgeable (Phillips \& Gentry 1993). The same holds true for conservation education programmes, where it may be impractical to target an entire community. In both cases, knowledge about wildlife can differ considerably among individuals in a community based on age, experiences, and numerous other socio-economic and demographic factors (Berkes et al. 2000).

The photographs used in this study as indicators of wildlife knowledge are incomplete measures of the diversity and extent of wildlife knowledge among the people living near Way Kambas National Park. For example, ecological knowledge of each species and the forest was not assessed. The knowledge does, however, provide a starting point to assess awareness among local villagers of elephants, tigers and other large mammals.

Large, charismatic and abundant animals like the elephant, tiger and deer were generally identified correctly more frequently than smaller or more secretive animals like the civets and the tapir. The relatively low knowledge scores for many of the animals also reflect the secretive nature of many mammals, the difficulty of observing wildlife in the dense secondary vegetation, and the relative abundance of these animals in the Park. Even among researchers and Park managers, rhinos were thought to be extinct within the Park until recently (Reilly et al. 1997). Many of the animals are rare or do not occur on Java and Bali (Whitten et al. 1996), the islands of origin for many of the respondents. For example, elephants and tapirs do not presently occur on Java and the critically endangered Javan rhino, which is similar to the Sumatran rhino used in the study, is found only in one reserve on that island. The Javan tiger, still abundant at the turn of the century, was limited to a handful of animals by the 1970s (Seidensticker 1987).

Nevertheless, $23 \%$ of respondents claimed to have observed a rhino. One explanation is that villagers who regularly enter the forest are more likely than occasional visitors to have actually seen these elusive animals. Another is that rhinos were almost certainly more abundant and may have avoided humans less before large-scale logging in the Park was carried out in the 1960s and 1970s. A third is that at least some of the respondents may have mistaken the pictured 
animal for a more common animal or guessed. The relatively high rate of tiger sightings $(40 \%)$ could be similarly interpreted, except that tigers are more likely to hunt or move along the forest edge, providing more opportunities for individuals to observe these animals.

Higher formal education has been shown to be associated with positive attitudes toward wildlife conservation and protected areas in South Asia (Heinen 1993), South America (Fiallo \& Jacobson 1995), and Africa (Infield 1988). Thus, it is not surprising that higher educational attainment is also associated with higher wildlife knowledge scores. Formal education provides increased opportunities for exposure to information about these animals, and literacy provides opportunities for people to learn from printed media and other sources. Individuals with more formal education might have greater facility with the Indonesian language and a higher comfort level with the question-and-answer interview format.

Lower knowledge scores among women are also not surprising. Men are more likely to enter the forest illegally to fish, hunt or to collect non-timber resources. Women enter the Park to collect grass and fuelwood, but rarely enter far beyond the edge of the Park boundary.

The lower knowledge scores among individuals who had lived more than 39 years in the area is somewhat surprising. We initially expected that the first settlers would have been the most likely to experience an abundance of wildlife and access to the forest before it was 'closed' to make the Park. One explanation is that at least some of these respondents had minimal interaction with the forest when they first arrived from agricultural areas of Java or Bali. An alternative explanation is that the very oldest respondents were less comfortable with Indonesian language, the survey format, or were more likely to have impairments that would affect their ability to respond to the survey questions.

This study suggests several implications that could have significance for biodiversity research, conservation and education in Sumatra. First, behavioural and morphological characteristics of animals may increase or decrease the probability of researchers obtaining accurate information from informants. Edge-loving species like deer or 'pest' species like elephants have a relatively high probability of being accurately identified. We hypothesize other species in Sumatra like wild boar (Sus scrofa), primates like long-tailed macaques (Macaca fascicularis), and ungulates like sambar deer (Cervus unicolor) would fit this category. Large, charismatic or widely-known species like the elephant and the tiger, which are used as symbols and permeate folk legends, also increase the probability that informants will provide accurate information about their presence, with the caveat that the name used to identify tigers is frequently confused with other felids (see below). The orangutan (Pongo pygmaeus), found in north Sumatra, would be another example of an animal in this category. In the case of Way Kambas, where elephant cropraiding is a frequent and significant problem (Nyhus et al. 2000), elephants would fit both these categories. Nocturnal, rare and shy animals are, not surprisingly, less likely to be identified correctly.

Second, it may be possible to increase the probability of finding knowledgeable individuals by selecting informants who share certain characteristics. Male gender, higher formal educational attainment, and years of residence were positively associated with differences in knowledge scores, whereas greater age was weakly associated. Knowledge scores were also significantly associated with whether or not respondents had personally observed these animals, with the exception of the tiger and the rhino. These distinctions are likely to have reflected different experiences with the forest among members of the communities near the Park. Young men were reputedly more likely to enter the forest to gather forest products or hunt, and older villagers and those who had lived in Lampung before the forests were logged were more likely to have had opportunities to see wildlife when they first arrived. Older villagers with long histories in the area often discussed how tigers, elephants and many other species would wander near their homes when the villages were first established from the 1950s to the 1970s. Today, with the exception of elephants and some pigs and deer, the number and variety of animals that ventured outside of the Park's border were few.

The survey results generally concurred with our informal interviews with village leaders. Individuals typically introduced to us by these leaders as 'knowledgeable' about the forest were often young or middle-aged men who were literate and entered the forest on a regular basis. Older villagers, including former loggers and hunters, were often introduced to us to answer our questions about the history of wildlife and land use in the area.

Third, terms used to describe a tiger may be the same as those used to describe other large cats or even some civets, and vice versa. The Javanese term macan is commonly used to describe all large cats, including tigers, leopards and even some civets, and has been adopted into the Indonesian vocabulary (Wessing 1986; Whitten et al. 1996). The Indonesian term harimau tends to be more specific to tigers, but we observed that it was also used loosely to describe other species, including the leopard. The large number of languages and dialects in use among people living near the Park could thus result in unintended confusion when discussing wildlife and conservation with villagers. Some might interpret a 'tiger' conservation education programme as a 'leopard' programme unless specific steps were taken to identify the animal through pictures and specific descriptions.

The use of wildlife knowledge assessments remains a common tool for biodiversity research and conservation programmes around the world. In China, for example, interviews with villagers near protected areas were recently used to confirm field studies indicating the extinction in the wild of the South China tiger (Panthera tigris amoyensis) (R. Tilson, J. Muntifering \& P.J. Nyhus, unpublished data 2002). In Papua New Guinea, observations from local experts 
informed efforts to model extinction risks to tree kangaroos (Dendrolagus sp.) and to develop emergency conservation and education programmes for this highly threatened species (Lacy \& Miller 2002).

However, this study also highlights the risk of overgeneralizing about 'local people,' a term frequently used in the park-people literature to describe people living in or near protected areas. While helpful as a descriptor, it may mask some of the considerable differences among individuals with different histories, socio-economic backgrounds and experiences with the protected area. We have not yet seen a concise discussion of the implications of communities composed of high proportions of migrants near protected areas for studies using traditional ecological knowledge. To further test the hypotheses suggested here, it would be valuable to compare these results to other protected areas in Sumatra and beyond to identify whether these are localized patterns or if they could be generalized to other areas. It would also be helpful to explicitly compare knowledge between migrant and nonmigrant populations living in the same area. The proportion of migrants and children of migrants in this study was so overwhelming, only 19 respondents (3\%) had both parents born in Sumatra. Thus, no detailed comparison of migrant and indigenous villagers living in the same area was possible. In hindsight, it would have been valuable to have included animals not actually found in the Park. The inclusion of such 'trick' questions may better identify informants who are guessing or otherwise biased in their responses.

\section{CONCLUSIONS}

This study identifies variations among villagers living adjacent to Way Kambas National Park in their ability to identify large mammals found within the Park. In communities with a high proportion of migrants, this study suggests it is possible that only large, common and well-known species might be correctly identified by a majority of respondents participating in wildlife knowledge surveys. Thus, wildlife assessments using local informants in such communities may be more effective for species like elephants, barking deer and tigers, and less effective for lesser known, rare or timid animals. Results for species that are morphologically similar to other animals (such as animals that are striped or look like cats) may be particularly vulnerable to misidentification.

This study is just a first step towards identifying key differences in knowledge levels. Additional comparative studies are necessary to identify whether this is a local phenomenon or a more generalized finding, and there is a need to explicitly explore to what extent photographs can be used as proxies for information about animal behaviour, ecology and other dimensions of indigenous ecological knowledge. Attention also should also be given to different perceptions of wildlife knowledge among local people and researchers. As $\mathrm{Ng}$ (2002) points out, there are considerable cultural differences even among scientists from different regions about perceptions of 'useful' and 'useless' categories of taxonomic and biodiversity knowledge.

A better understanding of the limitations of using the 'traditional' ecological knowledge of recent migrants and long-term settlers may improve the likelihood that research and conservation programmes for species like the endangered tiger will succeed. More and more people are living in close proximity to the world's last remaining wilderness areas (Sanderson et al. 2002). Time is running out in Sumatra and regions like it across Asia and around the world to identify areas where the world's last tigers, rhinos and other endangered species can still be found. Knowing what to look for and who to ask are good starting points for wildlife researchers hoping to augment or substitute rigorous field studies for endangered species research, conservation and education programmes.

\section{ACKNOWLEDGEMENTS}

We are grateful to the Indonesian Institute of Sciences, the Ministry of Forestry's Directorate of Forest Protection and Nature Conservation, the director and staff of Way Kambas National Park, staff and students of the University of Lampung, and staff of the Sumatran Tiger Project. We especially acknowledge the assistance of local community leaders and informants. This study was funded primarily by the Save The Tiger Fund of the USA National Fish and Wildlife Foundation in partnership with ExxonMobil, administered through the Minnesota Zoo Foundation. Additional support was received from The Rhinoceros and Tiger Conservation Fund of the US Fish and Wildlife Service and the US National Security and Education Program (to PJN). Other conservation partners of this component of the Sumatran Tiger Conservation Program include The Tiger Foundation (Canada), the Sumatran Tiger Trust (UK), Discovery Channel (Singapore) and Dreamworld (Australia).

\section{References}

Berkes, F. (1999) Sacred Ecology: Traditional Ecological Knomledge and Resource Management Systems. Philadelphia, USA: Taylor and Francis.

Berkes, F., Colding, J. \& Folke, C. (2000) Rediscovery of traditional ecological knowledge as adaptive management. Ecological Applications 10: 1251-1262.

Blouch, R.A. \& Haryanto (1984) Elephants in southern Sumatra. Unpublished report, World Wildlife Fund, Bogor, Indonesia.

Blouch, R.A. \& Simbolon, K. (1985) Elephants in northern Sumatra. Unpublished report, World Wildlife Fund, Bogor, Indonesia.

BPS (1995) Sensus Pertanian 1993: Analisis Pertanian Rumah Tangga Pertanian Propinsi Lampung. Jakarta, Indonesia: Biro Pusat Statistik.

Corbet, G.B. \& Hill, J.E. (1992) The Mammals of the Indomalayan Region: A Systematic Reviem. Oxford, UK: Oxford University Press. 
Departemen Pendidikan dan Kebudayaan (1989) Kamus Besar Bahasa Indonesia. Jakarta, Indonesia: Balai Pustaka.

Fearnside, P. (1997) Transmigration in Indonesia: Lessons from its environmental and social impacts. Environmental Management 21: $553-570$.

Fiallo, E.A. \& Jacobson, S.K. (1995) Local communities and protected areas: attitudes of rural residents towards conservation and Machalilla National Park, Ecuador. Environmental Conservation 22: 241-249.

Franklin, N., Bastoni, Sriyanto, Dwiatmo, S., Manansang, J. \& Tilson, R. (1999) Last of the Indonesian tigers: a cause for optimism. In: Riding the Tiger: Tiger Conservation in Human-dominated Landscapes, ed. J. Seidensticker, S. Christie \& P. Jackson, pp. 130-147. Cambridge, UK: Cambridge University Press.

Gadgil, M., Berkes, F. \& Folke, C. (1993) Indigenous knowledge for biodiversity conservation. Ambio 22: 151-156.

Heinen, J.T. (1993) Park-people relations in Kosi Tappu Wildlife Reserve, Nepal: a socio-economic analysis. Environmental Conservation 15: 25-34.

Huntington, H.P. (2000) Using traditional ecological knowledge in science: methods and applications. Ecological Applications 10: $1270-1274$.

Infield, M. (1988) Attitudes of a rural community towards conservation and a local conservation area in Natal, South Africa. Biological Conservation 45: 21-46.

Kellert, S.R. (1996) The Value of Life: Biological Diversity and Human Society. Washington, DC, USA: Island Press.

Lacy, R.C. \& Miller, P.S. (2002) Incorporating human populations and activities into population viability analysis. In: Population Viability Analysis, ed. S.R. Beissinger \& D.R. McCullough, pp. 490-510. Chicago, USA: University of Chicago Press.

Lekagul, B. \& McNeely, J.A. (1977) Mammals of Thailand. Bankgok, Thailand: Association for the Conservation of Wildlife.

Ministry of Forestry (1995) Way Kambas National Park management plan: 1994-2019. Unpublished report, Ministry of Forestry, Directorate General of Forest Protection and Nature Conservation, Bogor, Indonesia.

$\mathrm{Ng}$, F.S.P. (2002) Taxonomy, biodiversity and management of knowledge in Asia. Flora Malesiana Bulletin 13: 48-50.

Nowak, R.M. (1991) Mammals of the World. Baltimore, USA: The Johns Hopkins University Press.

Nowell, K. \& Jackson, P., eds. (1996) Wild Cats: Status Survey and Conservation Action Plan. Gland, Switzerland: IUCN.

Nyhus, P., Sumianto \& Tilson, R. (1999) The tiger human dimension in southeast Sumatra, Indonesia. In: Riding the Tiger: Tiger Conservation in Human-dominated Landscapes, ed. J. Seidensticker, S. Christie \& P. Jackson, pp. 144-145. Cambridge, UK: Cambridge University Press.

Nyhus, P., Sumianto \& Tilson, R. (2000) Crop-raiding elephants and conservation implications at Way Kambas National Park, Sumatra, Indonesia. Oryx 34(4): 262-275.

Phillips, O. \& Gentry, A. (1993) The useful plants of Tambopata, Peru: II. Additional hypothesis testing in quantitative ethnobotany. Economic Botany 47: 33-43.
Posey, D.A. (1993) Indigenous knowledge in the conservation and use of world forests. In: World Forests for the Future: Their Use and Conservation, ed. K. Ramakrishna \& G. Woodwell, pp. 59-77. New Haven, USA: Yale University Press.

Reilly, J., Spedding, G.H. \& Apriawan (1997) Preliminary observations on the Sumatran rhino in Way Kambas National Park, Indonesia. Oryx 31: 143-150.

Sanderson, E.W., Jaiteh, M., Levy, M.A., Redford, K.H., Wannebo, A.V. \& Woolmer, G. (2002) The human footprint and the last of the wild. BioScience 52: 891-904.

Santiapillai, C. \& Suprahman, H. (1985) Habitat management in Way Kambas Game Reserve with reference to the elephant population (WWF/IUCN Project 3133-No.2). Tigerpaper 12: 20-27.

Santiapillai, C. \& Jackson, P. (1990) The Asian elephant: an action plan for its conservation. Unpublished report, IUCN/SSC Asian Elephant Specialist Group, IUCN, Gland, Switzerland.

Scholz, U. (1983) The natural regions of Sumatra and their agricultural production pattern: a regional analysis. Unpublished report, Central Research Instititute for Food Crops, Bogor, Indonesia.

Seidensticker, J. (1987) Bearing witness: Observations on the extinction of Panthera tigris balica and Panthera tigris sondaica. In: Tigers of the World: The Biology, Biopolitics, Management, and Conservation of an Endangered Species, ed. R.L. Tilson \& U.S. Seal, pp. 1-8. Park Ridge, NJ, USA: Noyes Publications.

SPSS (1999) SPSS Base 9.0 Applications Guide. Chicago, USA: SPSS, Inc.

STP (1996) Field study progress report: six-month summary. Unpublished report, Sumatran Tiger Project, Apple Valley, MN, USA.

Tilson, R., Nyhus, P. \& Franklin, N. (2001) Tiger restoration in Asia: ecological theory vs. sociological reality. In: Large Mammal Restoration: Ecological and Sociological Challenges in the 21st Century, ed. D.S. Maehr, R.F. Noss \& J.L. Larkin, pp. 277-291. Washington, DC, USA: Island Press.

Tilson, R., Soemarna, K., Ramono, W., Sukumar, R., Seal, U., Traylor-Holzer, K. \& Santiapillai, C., eds. (1994a) Asian elephant in Sumatra: population and habitat viability analysis report. Unpublished report, IUCN/SSC Conservation Breeding Specialist Group, Apple Valley, MN, USA.

Tilson, R.L., Soemarna, K., Ramono, W., Lusli, S., TraylorHolzer, K. \& Seal, U.S. (1994b) Sumatran tiger population and habitat viability analysis report. Unpublished report, IUCN/SSC Conservation Breeding Specialist Group, Apple Valley, MN, USA.

Wessing, R. (1986) The Soul of Ambiguity: The Tiger in Southeast Asia. DeKalb, USA: Northern Illinois University.

Whitten, T., Soeriaatmadja, R.E. \& Afiff, S.A., eds. (1996) The Ecology of Java and Bali. Hong Kong: Periplus Editions.

World Bank (2001) Indonesia: environment and natural resource management in a time of transition. World Bank, Jakarta, Indonesia.

WWF (2000) Indigenous and traditional peoples of the world and ecoregion conservation. WWF-World-Wide Fund for Nature, Gland, Switzerland. 